\title{
Research and Comparison of Different Levels of Fertilizer Nano Zinc Chelates and Zinc Sulfate and Its Effect on the Growth Parameters of Parsley (Petroselinum crispum L.)
}

\author{
Hesam Vattani, Naser Vafaee, Alireza Ladan Moghadam, Narges Keshavarz
}

\section{ABSTRACT}

Parsley is a biennial plant from the Apiaceae family that is used in the food, pharmaceutical, perfume and cosmetic industries. This plant has various mineral such as $\mathrm{Fe}$ and vitamins including $\mathrm{A}, \mathrm{B}$ and $\mathrm{C}$ and grown in most parts of the world. Nano-fertilizers are a good alternative to sulfated fertilizers due to their higher solubility and gradual release of particles than conventional fertilizers. In order to investigate the effect of foliar application zinc on growth and yield of parsley, an experiment based on randomized complete blocks with 6 treatments and three replications was performed in the experimental field of Imam Khomeini Higher Agricultural Education Center. Treatments included foliar application of Nano zinc chelate fertilizer $(0.5,1$ and $1.5 \mathrm{~g} / \mathrm{L})$ and zinc sulfate $(1$ and $1.5 \mathrm{~g} / \mathrm{L})$. The foliar application was performed in 4 to 6 leaf stage and repeated every 14 days till before harvesting. Number of leaves, plant height, leaf area, leaf length and width, fresh and dry weight of leaves and stems were measured. The results showed that the highest amount of the mentioned traits was obtained in the foliar application of $1.5 \mathrm{~g} / \mathrm{L}$ Nano zinc chelate fertilizer and the lowest values were obtained at the control treatment. It is noteworthy that there is no significant difference between 1 and $1.5 \mathrm{~g} / \mathrm{L}$ Nano zinc chelate fertilizer in terms fresh and dry weight of leaves and stems and both treatments are statistically in the same group. Therefore, foliar application of $1 \mathrm{~g} / \mathrm{L}$ Nano zinc chelate fertilizer is economically recommended.

Keywords: Growth parameter, Nano-fertilizer, Parsley, Zinc chelate.
Published Online: January 13, 2021

ISSN: $2684-1827$

DOI: 10.24018 /ejfood.2021.3.1.220

\section{Hesam Vattani *}

Agricultural and Horticulture productions department, Islamic Azad University, Iran. (e-mail: vattani.hesam ${ }^{\circledR}$ gmail.com)

Naser Vafaee

Agricultural and Horticulture productions department, Islamic Azad University, Iran. (e-mail: naservafaee@gmail.com)

Alireza Ladan Moghadam

Agricultural and Horticulture productions department, Islamic Azad University, Iran.

(e-mail: dr.ladan91@yahoo.com)

Narges Keshavarz

Buali Sina Hamedan Uiversity, Iran.

(e-mail: keshavarzk_n@yahoo.com)

*Corresponding Author

\section{INTRODUCTION}

Parsley (Petroselinum crispum L.) is a biennial plant from the Apiaceae family which is used in food, pharmaceutical, perfume and cosmetic industries. This plant is widely cultivated in Asian countries [1]. Parsley has various mineral such as Fe and vitamins including C, B, A and has many uses in food preparation, which in this regard is grown in most areas. Parsley root has a diuretic and appetizing effect. Decoction of various parts of this plant is used in cases of tissue edema, general edema of the body, kidney stone disease, gastrointestinal disorders, bloating, jaundice, liver and spleen diseases, shortness of breath, amenorrhea due to weakness in young women and skin diseases. Other important effects are the treatment of hypertension, arthritis and tuberculosis. The leaf compounds of the plant increase the reduction capacity in plasma and reduces the oxidative stress and also its antimicrobial and antioxidant properties are known [2].

The therapeutic properties of parsley related to flavonoid, apine, glycosides, luteolin carotenoids, ascorbic acid, tocopherol, apigenin compounds, volatile compounds such as apiol, myristicin, Coumarin, Tocopherol, Phthalaldehyde, imperatorin, bergapten, phthalides, furanocoumarins, sesquiterpenes [3].

In ancient times, in addition to its medicinal and nutritional value, the parsley was used as a decoration for funeral crowns by the ancient Romans and Greeks with superstitious beliefs. They used parsley and parsley crowns for prizes at sports games. Parsley was used in the Hebrew celebration of Passover as a symbol of spring and rebirth. The ancient Greeks and Romans usually did not eat parsley. However, they grew the parsley in their gardens as a border, and it was thought to be a great food for chariot horses [4].

Origin of parsley (Petroselinum crispum) is the Mediterranean region. However, today it has grown all over the world. This plant grows up to 60 to $100 \mathrm{~cm}$. The parsley roots are morphologically thin, thick and vertical. Parsley roots and leaves are mainly consumed, and sometimes the seeds are used in medicinal compounds. It should be noted that parsley is a plant that is widely used in traditional medicine [5].

Improper and non-standard uses of chemical fertilizers can have a multifaceted and direct effect on soil quality and fertility, as well as the production of agricultural products, especially vegetables and products that are consumed directly without processing. The persistence and composition of these 
harmful substances has a serious threat to the society health of the current generation and future generations [6]. The uses of chelate forms, which are obtained by the reaction of metal salts with artificial and natural complexes, is the important way to protect iron against increasing the sediment in the soil by increasing the $\mathrm{pH}$ [7]. Zinc is the only element that acts as an activator and co-factor in all enzyme groups. Zinc has a direct effect on auxin biosynthesis, chlorophyll production and pollination. Most of the soils of Iran are saline, calcareous and poor in organic matter. Excessive use of phosphate fertilizers has reduced the use of zinc fertilizers. Reducing of plant and leaves growth along with yellowing of the young leaves are signs of zinc deficiency [8].

Nanotechnology is one of the most advanced and new technologies that is still in its infancy. Its combination with other sciences can bring effective results. The need to use a different scale from other similar technologies has distinguished Nanoscience. Nano-powders are a mixture of Nanometer-sized particles. Therefore, discussion and study of the different aspects and potential risks of Nanoparticles on human health, safety and the environment is very important and sensitive [9]. The recent advances in materials and chemistry science have made it possible to produce Nanoparticles that can be widely used in various fields of agriculture [10].

The most practical feature of Nanotechnology in various fields of agriculture and especially in the field of soil and water nutrition is the use of Nano-fertilizers for optimal use by plants. In new generations of Nanoparticles, polycyclic aromatic hydrocarbons are removed. These aromatic hydrocarbons are difficult to remove from water and soil [11]. In some cases, Nano-fertilizers have been shown to have a significant effect on physiological and morphological traits of plant. Nanoiron chelate fertilizer has increased the amount of total chlorophyll and ascorbic acid to the highest level in savory and parsley [12]. Foliar application of $1 \mathrm{~g} / \mathrm{L}$ of Nano zinc chelate fertilizer has increased the leaf area and length of the main inflorescence in holy basil [10]. In spinach, application of $4 \mathrm{~kg} / \mathrm{ha}$ of Nano-fertilizer increased $58 \%$ and $47 \%$ of fresh weight and leaf area index, respectively. Independent effect of Nano iron chelate fertilizer and Nano potassium fertilizer had the more effect on shoot dry weight, seed yield, mucilage content and mucilage yield in Plantago ovata [14]. It has been reported the highest percentage of seed oil $(45.2 \%)$, thousand-seed weight $(4.13 \mathrm{~g})$ and plant height $(106.5 \mathrm{~cm})$ were related to irrigation treatment in the whole growth period and combined foliar application of Nano zinc chelate and iron fertilizer in rapeseed [15]. Also, iron chelate Nano-fertilizer increased the total amount of chlorophyll a and b in Satureja hortensis [16].

In this study, the effect of foliar application of Nano zinc chelate fertilizer and zinc sulfate on the morphological characteristics of parsley (Petroselinum crispum L.) has been investigated.

\section{MATERIAL AND METHODS}

To investigate the effect of Nano-zinc chelate fertilizer (12\%) and zinc sulfate on growth characteristics and yield of parsley, the study was performed in a completely randomized block with 6 treatments and three replications in the crop years of 2018-2019 at experimental field of Imam Khomeini Higher Agricultural Education Center with a geographical location of $35^{\circ} 46^{\prime} 14.0^{\prime \prime} \mathrm{N}$ and $50^{\circ} 56^{\prime} 50.3^{\prime \prime} \mathrm{E}$. The first factor including the $0.5,1$ and $1.5 \mathrm{~g} / \mathrm{L}$ Nano zinc chelate fertilizer concentrations and the second factor including and $1.5 \mathrm{~g} / \mathrm{L}$ zinc sulfate concentrations. It should be noted that the control was also present in this experiment at zero concentration. Pre-planting soil preparation operations were deep plowing and two stages of perpendicular disk and distribution of basic fertilizers based on fertilizer recommendations of soil test results (Table I) including 100 $\mathrm{kg} / \mathrm{ha}$ triple superphosphate, $50 \mathrm{~kg} / \mathrm{ha}$ potassium sulfate and $50 \mathrm{~kg} / \mathrm{ha}$ urea. The soil samples botained from $25 \mathrm{~cm}$ depth and its important characteristics were tested. The field was divided into three blocks and six experimental units and stacks were created at intervals of $30 \mathrm{~cm}$. Parsley seedling were planted at a distance of $13 \mathrm{~cm}$ on these stacks. After planting the seedlings and after 5 days for complete establishment and full root stabilization, fertilization was done by foliar application of Nano zinc chelate fertilizer (12\%) and zinc sulfate with 14days interval (2 weeks). During the foliar application, weed weeding and regular irrigation were performed based on soil moisture. Spraying with 4-6.5 L/ha Deurinol, $8 \mathrm{~kg} / \mathrm{ha}$ Tenoran and $1.5 \mathrm{~kg} / \mathrm{ha}$ Afalon were also done before planting. Foliar application continued before the harvest and traits including yield, number of leaves, plant height, leaf area, fresh and dry weight of leaves and stems recorded. The leaf area calculated by using Delta-T Leaf Area Meter and chlorophyll content was obtained by Ritchie et al. [17] method. Then, analysis of variance and statistical data were calculated by SPSS and Excel software.

TABLE I: SOIL TEST RESULTS

\begin{tabular}{ccc}
\hline Texture & Unit & Sandy loam \\
\hline $\mathrm{PH}$ & & 7.9 \\
$\mathrm{EC}$ & $\mathrm{dS} / \mathrm{m}$ & 1.1 \\
$\mathrm{FC}$ & $\%$ & 11 \\
$\mathrm{~N}$ & $\%$ & 0.06 \\
$\mathrm{P}$ & $\mathrm{mg} / \mathrm{kg}$ & 2.5 \\
$\mathrm{~K}$ & $\mathrm{mg} / \mathrm{kg}$ & 350 \\
$\mathrm{FE}$ & $\mathrm{mg} / \mathrm{kg}$ & 2 \\
$\mathrm{~S}$ & $\mathrm{mg} / \mathrm{kg}$ & 24 \\
$\mathrm{MN}$ & $\mathrm{mg} / \mathrm{kg}$ & 16 \\
$\mathrm{Z}$ & $\mathrm{mg} / \mathrm{kg}$ & 2.05 \\
\hline
\end{tabular}

\section{RESULTS AND DisCUSSION}

\section{A. Plants Height}

The analysis of variance results (Table II) showed that the application of different levels of zinc sulfate and Nano zinc chelate fertilizer has a significant effect on plant height at the $1 \%$ probability.

The mean comparison results showed that the highest plant height $(41.5 \mathrm{~cm})$ was obtained by foliar application of $1.5 \mathrm{~g} / \mathrm{L}$ Nano zinc chelate fertilizer, which increased $41 \%$ compared to the control treatment $(24.3 \mathrm{~cm})$. After that, the plants that were sprayed with $1 \mathrm{~g} / \mathrm{L}$ Nano zinc chelate fertilizer had the highest height $(36.30 \mathrm{~cm})$. The data average indicated that the control plant and the plants treated with $1 \mathrm{~g} / \mathrm{L}$ zinc sulfate had the lowest height. The results of other researchers showed that micronutrients had an important role in biochemical activities vegetative growth and improving the 
photosynthetic process of leaves [4]-[6]. It is noteworthy that Rosrami Fard et al. [18] reported that the increasing of plant height is the result of increasing of cell division and elongation due to the use of zinc [18]. In addition, it is one of the important factors influencing the activity of tryptophan synthetase is. The tryptophan amino acid acts as a precursor for auxin production; so, with increasing the auxin production, the apical dominance increases, and the elongation of shoots also increases [19].

TABLE II: ANALYSIS OF VARIANCE RESUltS OF GROWTH YIELD OF PARSLEY

\begin{tabular}{|c|c|c|c|c|}
\hline $\begin{array}{c}\text { Source of } \\
\text { variance }\end{array}$ & Block & Treatment & Error & $\mathrm{Cv}(\%)$ \\
\hline Df & 2 & 5 & 10 & \\
\hline Parsley height & $1.57^{\mathrm{ns}}$ & $67.9^{\text {** }}$ & 0.53 & 1.10 \\
\hline Lai & $320.11^{\mathrm{ns}}$ & $31242.2^{* *}$ & 27020 & 11.2 \\
\hline $\begin{array}{c}\text { Number of } \\
\text { leaves }\end{array}$ & $190.01^{\mathrm{ns}}$ & $1010.1^{* *}$ & 799.20 & 13.2 \\
\hline Leaf length & $0.40^{\mathrm{ns}}$ & $150.2^{\text {** }}$ & 0.5 & 1.23 \\
\hline Leaf width & $1.31^{\mathrm{ns}}$ & $50.2^{* *}$ & 0.49 & 1.8 \\
\hline $\begin{array}{l}\text { Leaves fresh } \\
\text { weight }\end{array}$ & $0.9^{\mathrm{ns}}$ & $59.1^{* *}$ & 4.30 & 13.2 \\
\hline $\begin{array}{c}\text { Leaves dry } \\
\text { weight }\end{array}$ & $0.03^{\mathrm{ns}}$ & $2.2^{* * *}$ & 0.13 & 13.3 \\
\hline $\begin{array}{c}\text { Stem fresh } \\
\text { weight }\end{array}$ & $0.31^{\mathrm{ns}}$ & $12.13^{* *}$ & 0.9 & 11.5 \\
\hline $\begin{array}{l}\text { Stem dry } \\
\text { weight }\end{array}$ & $0.01^{\mathrm{ns}}$ & $0.39^{* *}$ & 0.03 & 12.8 \\
\hline
\end{tabular}

\section{B. Leaf Area Index}

The data showed that the effect of different treatments of zinc fertilizer on leaf area index at $1 \%$ probability were significant. The mean comparison of the data indicates that the application of $1.5 \mathrm{~g} / \mathrm{L}$ Nano zinc chelate fertilizer has produced the highest leaf area index $\left(2396.79 \mathrm{~cm}^{2}\right)$ which has no statistically significant differences1 g/L Nano-fertilizer and $1.5 \mathrm{~g} / \mathrm{L}$ zinc sulfate.

The lowest leaf area index $\left(272.2 \mathrm{~cm}^{2}\right)$ was observed in the control treatment which was in the same group with $0.5 \mathrm{~g} / \mathrm{L}$ Nano-fertilizer and $1 \mathrm{~g} / \mathrm{L}$ zinc sulfate.

Heidari et al. [20] reported that the use of micronutrients such as zinc, increases leaf area and number of glands secreted essential oil, which in turn increases the amount of essential oil in the plant.

\section{Number of Leaves}

The data in Table II shows the significant effect of treatments on the number of leaves at $1 \%$ probability. Mean comparison of data showed that, except the control and $1 \mathrm{~g} / \mathrm{L}$ zinc sulfate treatments, the other treatments had a similar effect on the number of leaves and were in the same group. However, foliar application of $1.5 \mathrm{~g} / \mathrm{L}$ zinc sulfate with 26 leaves, increased the number of leaves by $68 \%$ compared to the control. Khalid's [21] reports showed that micronutrients such as $\mathrm{Fe}, \mathrm{Mg}$ and $\mathrm{Zn}$ increased the number of leaves and essential oils of anise, coriander, and fennel.

\section{Leaf Length and Width}

The analysis of variance table showed that the treatments had a significant effect on leaf length and width at $1 \%$ probability. Mean comparison of data showed that the highest leaf length $(44.2 \mathrm{~mm})$ and leaf width $(26.32 \mathrm{~mm})$ were obtained by applying $1.5 \mathrm{~g} / \mathrm{L}$ Nano zinc chelate fertilizer, followed by treatments of $1 \mathrm{~g} / \mathrm{L}$ Nano-fertilizer and $1.5 \mathrm{~g} / \mathrm{L}$ zinc sulfate had the highest size at the same group. Findings of Moghimi Pour et al. [22] in the study of the effect of zinc foliar application showed that $1.5 \mathrm{~g} / \mathrm{L}$ Nano-chelate treatment produced the highest leaf size. The lowest leaf length was obtained in the control treatment and the application of $1 \mathrm{~g} / \mathrm{L}$ zinc sulfate and the lowest leaf width observed in the control treatment. As seen in Table IV, there is a positive and significant correlation at $1 \%$ probability between plant height and number of leaves, size and leaf area. Therefore, in the treatment of foliar application with zinc, the size and number of leaves increased with increasing the plant height.

\begin{tabular}{|c|c|c|c|c|c|c|}
\hline Treatments & $\mathrm{C}$ & $\begin{array}{l}\text { ZINC- } \\
\text { SU } 1\end{array}$ & $\begin{array}{c}\text { ZINC- } \\
\text { SU } 2\end{array}$ & N ZN 1 & $\begin{array}{c}\text { N ZN } \\
2\end{array}$ & $\begin{array}{c}\mathrm{N} \mathrm{ZN} \\
3\end{array}$ \\
\hline $\begin{array}{c}\text { Parsley } \\
\text { height } \\
(\mathrm{cm})\end{array}$ & $24.3^{\mathrm{e}}$ & $25.42^{\mathrm{e}}$ & $34.20^{\mathrm{d}}$ & $29.60^{d}$ & $36.30^{\mathrm{b}}$ & $41.5^{\mathrm{a}}$ \\
\hline Lai $\left(\mathrm{cm}^{2}\right)$ & $72.22^{\mathrm{b}}$ & $101.2^{\mathrm{b}}$ & $367.21^{\mathrm{a}}$ & $183.88^{\mathrm{b}}$ & $374.31^{\mathrm{a}}$ & $396.79^{\mathrm{a}}$ \\
\hline $\begin{array}{c}\text { Number of } \\
\text { leaves }\end{array}$ & $85.34^{\mathrm{b}}$ & $97.60^{\mathrm{b}}$ & $257.3^{\mathrm{a}}$ & $190.9^{\mathrm{a}}$ & $261.4^{\mathrm{a}}$ & $269.50^{\mathrm{a}}$ \\
\hline $\begin{array}{l}\text { Leaf } \\
\text { length }\end{array}$ & $21.43^{\mathrm{d}}$ & $23.02^{\mathrm{d}}$ & $39.1^{\mathrm{b}}$ & $28.28^{c}$ & $40.31^{\mathrm{b}}$ & $44.2^{\mathrm{a}}$ \\
\hline Leaf width & $13.57^{\mathrm{e}}$ & $15.44^{\mathrm{d}}$ & $24.29^{\mathrm{b}}$ & $18.31^{\mathrm{c}}$ & $24.51^{\mathrm{b}}$ & $26.32^{\mathrm{a}}$ \\
\hline $\begin{array}{c}\text { Leaves } \\
\text { fresh } \\
\text { weight }\end{array}$ & $3.71^{\mathrm{b}}$ & $4.94^{\mathrm{b}}$ & $15.35^{\mathrm{a}}$ & $7.5^{\mathrm{b}}$ & $15.93^{\mathrm{a}}$ & $16.35^{\mathrm{a}}$ \\
\hline $\begin{array}{c}\text { Leaves dry } \\
\text { weight }\end{array}$ & $0.27^{\mathrm{b}}$ & $1.02^{\mathrm{b}}$ & $3^{\mathrm{a}}$ & $1.28^{\mathrm{b}}$ & $3.083^{\mathrm{a}}$ & $3.1^{\mathrm{a}}$ \\
\hline $\begin{array}{c}\text { Stem fresh } \\
\text { weight }\end{array}$ & $1.66^{\mathrm{c}}$ & $1.86^{\mathrm{c}}$ & $6.35^{\mathrm{ab}}$ & $4.57^{\mathrm{b}}$ & $7.65^{\mathrm{a}}$ & $7.89^{\mathrm{a}}$ \\
\hline $\begin{array}{l}\text { Stem dry } \\
\text { weight }\end{array}$ & $0.29^{b}$ & $1.01^{\mathrm{b}}$ & $2.99^{\mathrm{a}}$ & $1.36^{\mathrm{b}}$ & $3.12^{\mathrm{a}}$ & $3.14^{\mathrm{a}}$ \\
\hline
\end{tabular}

In the table, zinc sulfate with concentrations of 1 and $1.5 \mathrm{~g} / \mathrm{L}$ showed with the abbreviation zn-su and Nano-fertilizer with concentrations of $0.5,1$ and $1.5 \mathrm{~g} / \mathrm{L}$ showed with the abbreviation $\mathrm{N}$ Zn.

In each column, all means that have at least one common letter do not have a statistically significant difference at the level of 0.01 .

TABLE IV: THE CORRELATION OF GROWTH TRAITS AND GROWTH YIELD TABLE IV: THE CORRELATION OF GROWTH TRAITS AND
OF PARSLEY (PETROSELINUM CRISPUM L.)

\begin{tabular}{|c|c|c|c|c|c|c|c|c|}
\hline & 1 & 2 & 3 & 4 & 5 & 6 & 7 & 8 \\
\hline $\begin{array}{l}\text { Parsley } \\
\text { height }\end{array}$ & 1 & & & & & & & \\
\hline $\begin{array}{c}\text { Number } \\
\text { of } \\
\text { leaves }\end{array}$ & $0.85^{* *}$ & 1 & & & & & & \\
\hline Lai & $0.86^{* *}$ & $0.97^{* *}$ & 1 & & & & & \\
\hline $\begin{array}{c}\text { Leaves } \\
\text { fresh } \\
\text { weight }\end{array}$ & $0.85^{* *}$ & $0.95^{* *}$ & $0.99^{* *}$ & 1 & & & & \\
\hline $\begin{array}{c}\text { Leaves } \\
\text { dry } \\
\text { weight }\end{array}$ & $085^{* *}$ & $0.95^{* *}$ & $0.94^{* *}$ & $0.99^{* *}$ & 1 & & & \\
\hline $\begin{array}{c}\text { Stem } \\
\text { fresh } \\
\text { weight }\end{array}$ & $0.88^{s *}$ & $0.94^{* *}$ & $0.94^{* *}$ & $0.94^{* *}$ & $0.97^{* *}$ & 1 & & \\
\hline $\begin{array}{c}\text { Stem } \\
\text { dry } \\
\text { weight }\end{array}$ & $0.87^{* *}$ & $0.97^{* *}$ & $0.94^{* *}$ & $0.99^{* *}$ & $0.97^{* *}$ & $0.99^{* *}$ & 1 & \\
\hline $\begin{array}{c}\text { Leaf } \\
\text { length }\end{array}$ & $0.96^{* *}$ & $0.85^{* *}$ & $0.92^{* *}$ & $0.92^{* *}$ & $0.90^{* *}$ & $0.91^{* *}$ & $0.99^{* *}$ & 1 \\
\hline $\begin{array}{c}\text { Leaf } \\
\text { width }\end{array}$ & $0.96^{* *}$ & $0.85^{* *}$ & $0.90^{* *}$ & $0.89^{* *}$ & $0.89^{* *}$ & $0.90^{* *}$ & $0.96^{* *}$ & $0.99^{* *}$ \\
\hline
\end{tabular}

Significant at $1 \%$ level.

\section{E. Leaves Fresh and Dry Weight}

Analysis of variance table showed that the foliar application had a significant effect on leaves fresh and dry weight at $1 \%$ probability. Mean comparison of data indicates that foliar application of 1 and $1.5 \mathrm{~g} / \mathrm{L}$ Nano zinc chelate fertilizer and $1.5 \mathrm{~g} / \mathrm{L}$ zinc sulfate increased the leaves fresh and dry weight and were in the statistically same group. The 
control treatment with foliar application of $0.5 \mathrm{~g} / \mathrm{L}$ Nanofertilizer and $1 \mathrm{~g} / \mathrm{L}$ zinc sulfate were in the statistically same group and produced the lowest leaves fresh and dry weight. Foliar application of $1.5 \mathrm{~g} / \mathrm{L}$ Nano-chelate fertilizer increased fresh and dry weight $77 \%$ and $91 \%$ compared to the control, respectively. Nahed and Balbaa [23] reported that application of $\mathrm{Zn}$ increases fresh and dry weight of parsley, periwinkle, and common sage.

Bayati [24] reported that the increases of dry matter by application of micronutrients such as zinc related with various reasons including increasing auxin biosynthesis in the presence of zinc, increasing carbonic anhydrase enzyme which is present in all photosynthetic tissues and is required for chlorophyll biosynthesis, improvement of optical photosystems performance, increasing phosphovanol pyruvate carboxylase and ribulose bisphosphate carboxylase activity, decreasing sodium accumulation in plant tissues, and increasing nitrogen and phosphorus uptake in the presence of zinc.

\section{F. Steam Fresh and Dry Weight}

The results of analysis of variance showed that zinc foliar application had a significant effect on stem fresh and dry weight at $1 \%$ probability (Table II). Mean comparison of the data indicates that the highest stem fresh weight $(7.89 \mathrm{~g})$ and dry weight $(3.14 \mathrm{~g})$ were obtained with foliar application of $1.5 \mathrm{~g} / \mathrm{L}$ Nano zinc chelate fertilizer, which was not statistically significant difference with $1 \mathrm{~g} / \mathrm{L}$ Nano-fertilizer and $1.5 \mathrm{~g} / \mathrm{L}$ zinc sulfate and were in the same group. Foliar application of $1 \mathrm{~g} / \mathrm{L}$ zinc sulfate with control treatment were statistically in the same group and had the lowest stem fresh and dry weight. Also, the lowest stem dry weight was related to the control treatment, which was statistically in the same group with foliar application of $0.5 \mathrm{~g} / \mathrm{L}$ Nano-fertilizer and 1 $\mathrm{g} / \mathrm{L}$ zinc sulfate. Tarraf et al. [25] reported that foliar application of $\mathrm{Zn}$ on rosemary medicinal plant had a positive and significant effect on the fresh and dry yield.

\section{CONCLUSION}

The main plant organ in leaf photosynthesis. And its crucial role in the production of assimilates in the plant cannot be ignored. By increasing the number of leaves and leaf area and the plant's effective use of light, food production raises and subsequently we will have incremental trend of photosynthesis. Thus, under no circumstances should not be overlooked fundamental role of zinc chelate Nano fertilizer in soil with high electrical conductivity and direct effect to plant growth.

The results obtained from the study of the effect of zinc fertilizer on parsley indicated that foliar application of zinc fertilizer had a positive effect on morphological traits. regard to the number of leaves, leaf size and leaf area have a positive correlation with plant weight, raising these traits will increase the fresh and dry weight of the plant. According to the effect of zinc on auxin biosynthesis, chlorophyll formation and production, it can be deduced that spraying application of this element will have a decisive effect on incremental trend of photosynthesis [26]. raising of photosynthesis with consumption of the zinc will enhancement the morphological characteristics of the plant. In this study, leaf spraying unit
$1.5 \mathrm{~g} / \mathrm{L}$ Nano zinc chelate fertilizer had the highest amount in all Parsley criteria. Hence this applied method is recommended. On the other side, if only the fresh and dry weight of the plant is examined without considering other agents, the treatment of $1 \mathrm{~g} / \mathrm{L}$ Nano-fertilizer and $1.5 \mathrm{~g} / \mathrm{L}$ is not statistically significant different; thus, foliar application of $1 \mathrm{~g} / \mathrm{L}$ Nano zinc chelate fertilizer would be economical. With further precisely researches, it can be concluded that Nano -zinc fertilizers are perfectly absorbed by the plant and well compensate the nutritional needs and deficiencies. Nano fertilizers have a competitive price, higher efficiency, high solubility in water and more stability forms than the sulfate fertilizer. mainly, Nano technology as a leading science in solving problems and issues of agriculture about sustainable environment, has well proven its position in agricultural and horticulture sciences and other related industries. Koocheki and Khajeh-Hosseini [27]. By the way suggested that this research be done on the reproductive forms of the plant [27].

\section{REFERENCES}

[1] A. Zargari, ed. Medicinal plants, 6th ed. Tehran: Tehran University Publication, 1996, pp.64. [In Persian].

[2] R. Yanardag, S. Bolkent, A. Tabakoglu-Oguz, and O. Ozsoy-Sacan, Effects of (Petroselinum crispum) extract on pancreatic B cells and blood glucose of streptozotocin-induced diabetic rats. Biol Pharm Bull, Vol. 26, pp. 1206-10, 2003.

[3] G.W. Francis, and M. Isaksen, Droplet counter current chromatography of the cartenoids of parsley Petroselinum crispum. Chromatographia, Vol. 27, pp. 549-51, 1989.

[4] M.H. Spraul, S. Nitz, and F. Drawert, The chemical composition of parsley root and seed extracts. Chem Microbiol Technol Lebensm, Vol. 13, pp. 179-82, 1991.

[5] Tucker, and DeBaggio, Isthmain. 2009.

[6] A. Koocheki, and M. Khajeh-Hosseini, Modern agriculture. Mashhad SID Press. 2008, 704 pages.

[7] A. L. Köksal, H. Dumanoglu, N. Tuna Günes, and M. Aktas, The effects of different amino acid chelate foliar fertilizers on yield, fruitquality, shoot growth and Fe, 1998.

[8] T. Islamzadeh, and B. Khaldbarin, Higher plant nutrition. Shiraz University Publications, 2005, pp. 495-499.

[9] M. H. Banaei, A. Moameni, M. Baybordi and M.J. Malakouti, The soils of Iran. Tehran: Sana publication, new achievements in perception. Managements and use, 2005.

[10] A. Johnson, (2006). Agriculture and Nanotechnology. Available: http://tahan. com/Charlie/Nanosociety.

[11] D. Warheit, G. Oberdoerster, The potential Nanotechnology White Paper, pp. 68-70, 2005

[12] E. Danaee, and V. Abdossi, 2019. Evaluation of the effect of foliar application of iron, potassium and zinc Nanochelate on the enzymatic activity and nutritional value of some leafy vegetables. Journal of Food Technology and Nutrition. Vol. 16. No. 2, pp. 45-54.

[13] L. Moghadam, and H. Vattani, Effect of Different Levels of Fertilizer Nano_Iron Chelates on Growth and Yield Characteristics of Two Varieties of Spinach (Spinacia oleracea L.): Varamin 88 and Viroflay. Research Journal of Applied Sciences, Engineering and Technology, 2012.

[14] D. Aghazadeh-Khalkhali, A. Mehrafarin, V. Abdossi, and H. Naghdi Badi, Mucilage and Seed Yield of Psyllium (Plantago psyllium L.) in Response to Foliar Application of Nano-iron and Potassium Chelate Fertilizer. J. Med. Plants, Vol. 14, No.56, pp.23-34, 2015.

[15] T. Ardeshiri, and S. Jahan Bin, Effect of foliar application of Nanoiron and zinc chelated on yield, yield components and harvest index of canola under drought stress conditions. Journal of Crops Improvment. Vol. 20, No.1, pp. 31-43, 2018.

[16] M. Peyvandi, M. Mirza, and Z. Kamali Jamakani, The Effect of Nano $\mathrm{Fe}$ chelate and $\mathrm{Fe}$ chelate on the growth and activity of some antioxidan, NCMBJ., Vol. 2, No.5, pp. 25-32, 2011

[17] S. W., Ritchie, and H. T. Nguyen, Leaf water content and gas exchange parameters of two wheat genotypes differing in drought resistance. Crop Science, Vol. 30, pp. 105-111, 1990.

[18] S. Rosrami fard, A. Khourgami, M. Rafee, and H. Nasrollahi, Study the effect of zinc spraying and plant density on seed yield and 
morphological characteristics of Green gram. Annals of Biological Research, Vol. 3, No. 8, pp. 4166-4171, 2012.

[19] Y. Nasiri, S. Zehtab-Salmasi, S. Nasrullahzadeh, N. Najafi, and K. GhassemiGolezani, Effects of foliar application of micronutrients ( $F e$ and $\mathrm{Zn}$ ) on flower yield and essential oil of Chamomile (Matricaria chamomilla). Journal Medicinal Plants Research, Vol. 4, No. 17, pp. 1733-1737, 2010.

[20] F. Heidari, S. Zehtab Salmasi, A. Javanshir, H. Aliari, and M. R. Dadpoor, The effects of application microelements and plant density on yield and essential oil of peppermint (Mentha piperita L.). Iranian Journal of Medicinal and Aromatic Plants. Vol. 24, No. 1, pp. 1-9, 2008.

[21] Kh. A. Khalid, "Effect of fertilization on the growth, yield and chemical composition of some medicinal Umbelleferous plant". M.S thesis, Dept. Agriculture. Al-Azhar Univ., Cairo, pp: 14-29, 1996.

[22] Z. Moghimi Pour, M. Mahmoodi Sourestani, N. Alemzade Ansari, and Z. Ramezani, The influence of foliar application of Nano zinc chelate and zinc sulfate on morphological traits of holy basil (Ocimum sanctum). Journal of Plant Production. Vol. 38, No. 3, pp. 41-53, 2015.

[23] G. Nahed, and L.K. Balbaa, Influence of tyrosine and zinc on growth, flowering and chemical constituents of Salvia farinacea plants. Journal Application Science, Vol. 3, No. 11, pp. 1479-1489, 2007.

[24] F. Bayati, A. Aynehband, and E. Fateh, Effect of different rates and application times of Nano-iron on yield and yield components of canola (Brassica napus L.). Iranian Journal of Field Crops Research, Vol. 12, No. 4, pp. 805-812, 2014.

[25] S.h. Tarraf, A.A. El-Sayed, and M.E. Ibrahim, Effect of some micronutrients on Rosmarinus afficinalis. Journal Physiological Science, Vol. 18, No. 1, pp. 201-208, 1994.

[26] Kh.A. Khalid, "Effect of fertilization on the growth, yield and chemical composition of some medicinal Umbelleferous plant". M.S thesis, Dept. Agriculture, Al-Azhar Univ., Cairo, pp: 14-29, 1996.

[27] A. Koocheki, and M. Khajeh-Hosseini, Modern agriculture. Mashhad SID Press. 2008, 74 pages.

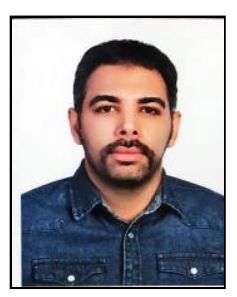

Hesam Vattani was born in Tehran, Iran in 1985. He is a graduate of Plant Production Engineering with a master's degree from the Islamic Azad university GARMSAR Branch in 2012 and is researching in horticulture and modern agricultural sciences.

$\mathrm{He}$ is one of his job titles in Green Architects Company as an expert in agriculture and promotion of the application of modern agricultural sciences and director of research and promotion of green architects in Tehran and lecturer at the University of Science and Technology in Karaj. $\mathrm{He}$ has published two articles and a book. His special research on nanoparticles also shows his interest in nanoparticles. Effect of Different Levels of Fertilizer Nano_Iron Chelates on Growth and Yield Characteristics of Two Varieties of Spinach (Spinacia oleracea L.): Varamin 88 and Viroflay. November 2012.Research Journal of Applied Sciences, Engineering and Technology 4(22):4813-4818.

Effect of sprayed Soluble different levels of iron chelate Nano fertilizer on nutrient uptake efficien cy in two varieties of spinach (Varamin88 And Virofly) International Research Journal of Applied and Basic Sciences ISSN 2251-838.

Mr. Vattani is an active member of the IFLA Association and Agricultural Engineering System and of course he has received the award for the best environmental designer with the feature of environmental sustainability from the Flower and Plant Exhibition in 2018.

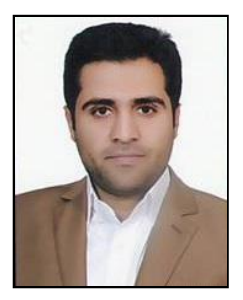

Naser Vafaee was born in Tehran, Iran in 1982. He is a graduate of Plant Production Engineering with a master's degree from the Islamic Azad University, Garmsar Branch in 2019 and He works in the field of science related to agricultural laboratory.

He works in Adineh Mehr Company as an active member in the laboratory and laboratory data in agricultural biotechnology as an agricultural expert. Mr Vafaee is a member of Agricultural Engineering in Horticulture and has been actively involved in holding scientific conferences for several years.

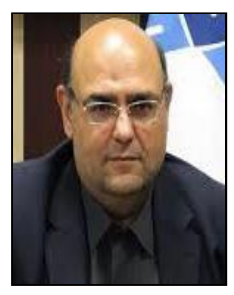

Alireza Ladan Moghadam was born in Tehran, Iran in 1965. He is a graduate of Plant Production Engineering with a master's degree from the Islamic Azad University, GARMSAR Branch in 2019 and $\mathrm{He}$ works in the field of science related to agricultural laboratory.

He holds a PhD in Horticulture from the Islamic Azad University, Research Sciences Branch, Tehran. In addition to his activities and membership in specialized committees of horticultural sciences, he is in charge of the scientific education department of SAMA organizations.

Dr Ladan Moghadam is a member of SAMA Organization and Tehran Agricultural Engineering System.

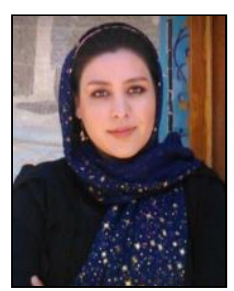

Narges Keshavarz was born in Tehran, Iran in 1986. She is graduated in agriculture with a master's degree from Bo Ali Sina University in Hamadan in 2011. He is currently working as an expert in Khazra Company, one of the companies active in the field of research and production of new pesticides and fertilizersHe has published two articles. Effect of Different Levels of Fertilizer Nano_Iron Chelates on Growth and Yield Characteristics of Two Varieties of Spinach (Spinacia oleracea L.): Varamin 88 and Viroflay. November 2012.Research Journal of Applied Sciences, Engineering and Technology 4(22):4813-4818.

Effect of sprayed Soluble different levels of iron chelate Nano fertilizer on nutrient uptake efficien cy in two varieties of spinach (Varamin88 And Virofly) International Research Journal of Applied and Basic Sciences ISSN 2251-838.

Mrs Keshavarz is an official member of the Agricultural Engineering System Organization. 